\title{
EVALUATION THE EFFECT OF FEYNAN ECOLODGE DECENTRALIZED WASTEWATER TREATMENT INFRASTRUCTURE DANA, TAFILA GOVERNORATE AT THE GROUNDWATER RESOURECES IN THE AREA - A CASE STUDY SOUTHERN OF JORDAN
}

\section{Dr.Mahmoud Al-Alawneh}

Ministry of Water and Irrigation/ Water Authority of Jordan

\section{ABSTRACT}

The main aims of this project aims to promote robust, easy-to-build, easy-to-operate, proven, flexible and sustainable decentralized wastewater treatment (DWWT) technologies in combination with the reuse of treated wastewater and to evaluate effects of this project at the groundwater recourses in the area. In the present research paper, the DRASTIC Models calculation was applied to evaluate the effects at groundwater in the study area. This calculation was used to perform the DRASTIC INDEX basis at different factors.

On behalf of the Federal Ministry for Economic Cooperation and Development the Project "Decentralized Wastewater Management for Adaptation to Climate Change in Jordan" (ACCProject) is supporting partner organizations in decentralized wastewater management (DWWM) as a measure for adaptation to climate change. The project is carried out in cooperation with the Jordanian Ministry of Water and Irrigation (MWI) via the Water Authority of Jordan (WAJ).Certain project activities are carried out in the Dana Biosphere Reserve in collaboration with the Royal Society for the Conservation of Nature (RSCN) and the private operator of Ecolodge in Feynan, EcoHotels. The German Non-Government Organization Bremen Overseas Research and Development Association (BORDA) is an implementing partner of the project.

As an adaptation measure the project promotes efficient use of water resources by a twofold approach: groundwater resources are protected by reduced pollution with untreated WW. At the same time, treated WW is reused thus substituting freshwater.

Key words: DRASTIC Model, DRASTIC INDEX, Groundwater Recourses, Climate Change

\section{Introduction}

Water is one of Jordan's scarcest resources; about 80 percent of the country is steppe and desert where water is only minimally available. Most of the municipal water supply systems and industry in Jordan presently depend on groundwater and springs. Most of these sources are currently being extracted to or beyond the capacity of the reliable aquifer yields, (MWI, 2012). The present use of water resources in the research area is dependent on the groundwater resources (mainly pumped wells).

Rainfall is the primary source of water in the study area. The mean annual rainfall in the catchment area is less than $\mathbf{1 0 0}$ 
mm at project area (According to Dana Climatology station) to about $200 \mathrm{~mm}$ at other part of the catchment, (JMD, 2015).

The imbalance between water needs and availability is exacerbated by inefficient and uncontrolled use as well as decreasing quality. 1Climate models predict a reduction of overall precipitation in Jordan of up to 60 percent by the end of this century. Currently, only around 67 percent of households are connected to the sewage system. Hence, there is a significant, untapped potential for decentralized approaches for wastewater (WW) management.

\section{PROJECT LOCATION}

$$
\text { Piloting activities will be }
$$
implemented at Feynan Ecolodge which's located on the lower entrance of the Dana Biosphere Reserve in Wadi Araba, table 1 represent the coordination of the project site, while figures (1a, b) represent the location of the project.
Currently no adequate wastewater treatment plant (WWTP) exists, the existing septic tank is irregularly emptied; potential groundwater pollution due to leakages, pollution of the wadi with the effluent as the treatment process is not complete/not efficient. Also WW reuse in this particularly dry environment is currently not practiced. The location was selected as the ecological and environmentally sustainable concept of the lodge fits perfectly with the concept of local wastewater treatment plant and reuse with close-to-nature DWWTPs.

The DWWTP will be accompanied by a reuse component: The treated wastewater will be used on-site for the planting of native trees around the Ecolodge. The main purpose of the reuse component is to improve the micro-climate around the lodge to create favorable conditions for the tourists.

Table 1: Project site coordinates (UTM Coordination)

\begin{tabular}{|l|l|l|}
\hline & LAT & LONG \\
\hline 1 & $30^{\circ} 38^{\prime} 22.92^{\prime \prime} \mathrm{N}$ & $35^{\circ} 30^{\prime} 32.14^{\prime \prime} \mathrm{E}$ \\
\hline 2 & $30^{\circ} 38^{\prime} 23.11^{\prime \prime} \mathrm{N}$ & $35^{\circ} 30^{\prime} 33.36^{\prime \prime} \mathrm{E}$ \\
\hline 3 & $30^{\circ} 38^{\prime} 21.60^{\prime \prime} \mathrm{N}$ & $35^{\circ} 30^{\prime} 33.63^{\prime \prime} \mathrm{E}$ \\
\hline 4 & $30^{\circ} 38^{\prime} 21.54^{\prime \prime} \mathrm{N}$ & $35^{\circ} 30^{\prime} 32.48^{\prime \prime} \mathrm{E}$ \\
\hline
\end{tabular}

${ }^{1}$ Decentralized Wastewater Management for Adaption to Climate Change in Jordan (ACC Project), 2016, Decentralized Wastewater Management: The Challenge 
Ass. Univ. Bull. Environ. Res. Vol. 21 No. 2 October 2018

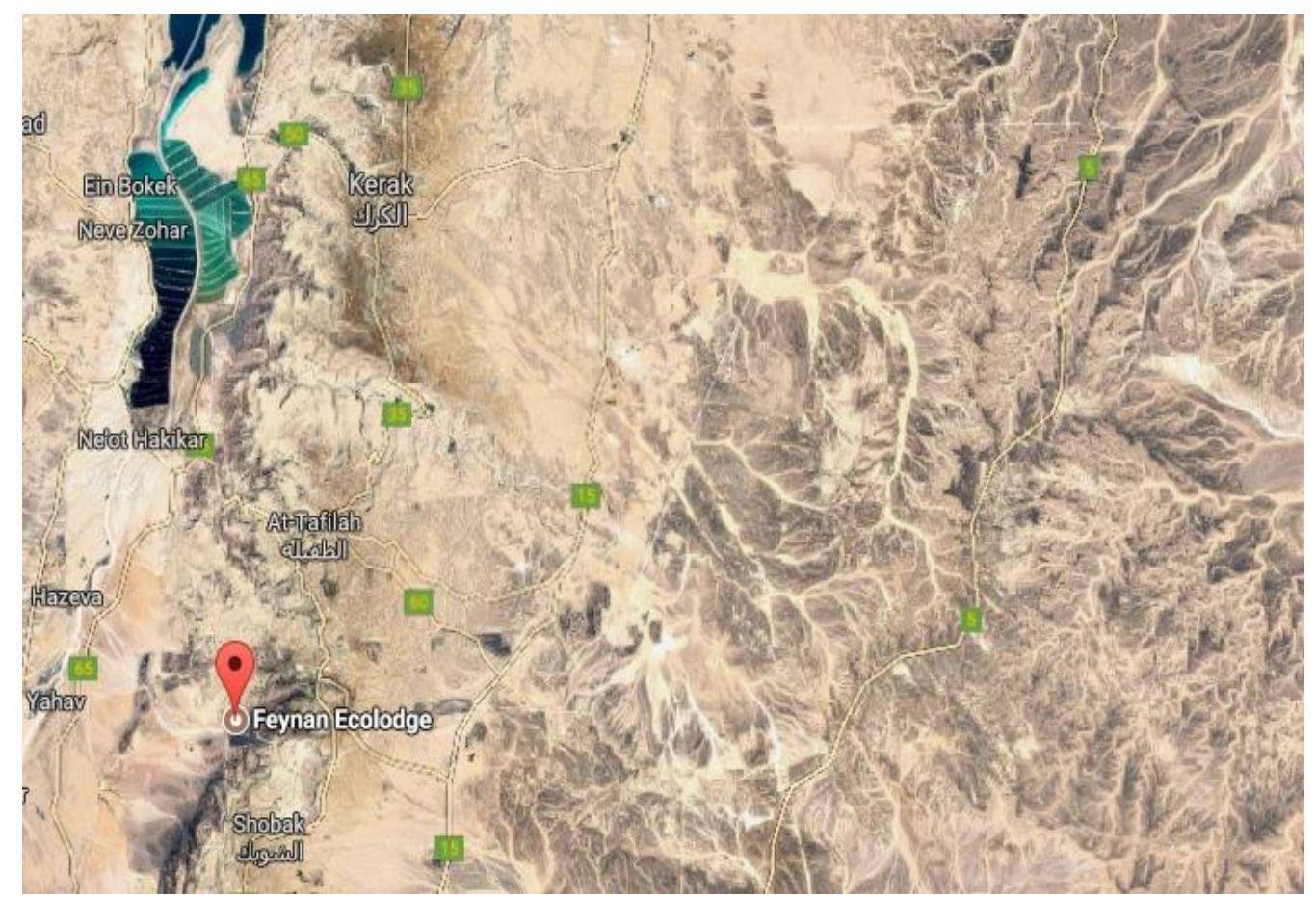

Figure 1a: Location of Feynan Ecolodge, Dana Biosphere Reserve

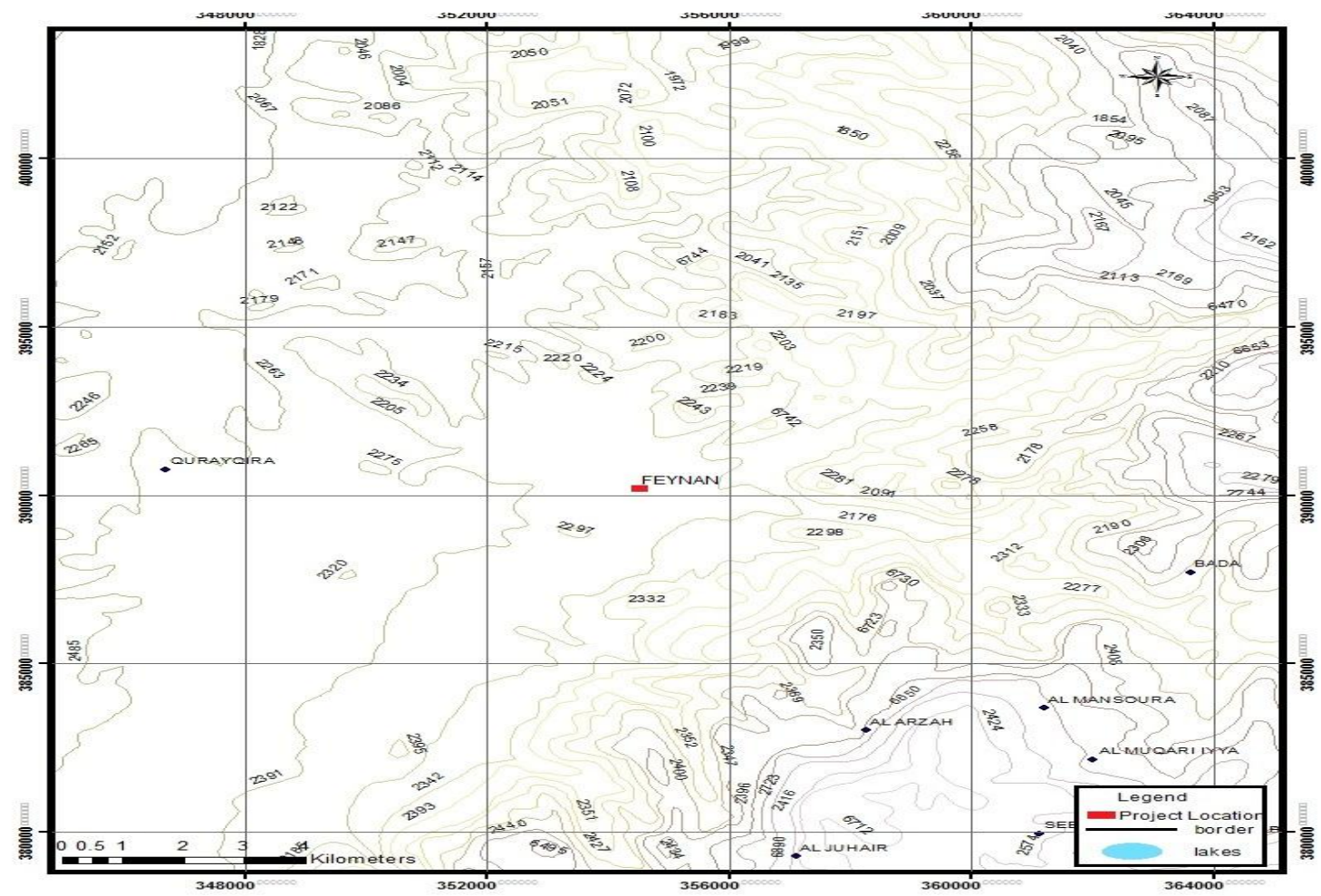

Figure 1b: Location of Feynan Ecolodge, Dana Biosphere Reserve 


\section{DESCRIPTION OF EXISTING} CONDITIONS

\section{Topography}

The general topography of the

Feynan Ecolodge where the project will be located is rolling to hilly, with some steep wadis. The elevation is around $350 \mathrm{~m}$ above sea level. While the range in altitude on the scarp slope varies from approximately $300 \mathrm{~m}$ above sea level at the Ghuwayr - Dana confluence on the alluvial plain to $1300 \mathrm{~m}$ above sea level on the plateau.

\section{Climate}

The climate of the project site is currently classified as semi-arid as annual potential evaporation exceeds precipitation and is characterized by relatively cold winters, with occasional rain, and mild to hot summers. The main climatology stations near the Project site is Dana climatology station. According to the long term recorded data at Dana station, the rate of annual rainfall is less than $100 \mathbf{~ m m}$ at Feynan Ecolodge where the project site is located to about $200 \mathrm{~mm}$ in the other part. It is characterized by warm winter and very hot summer, the temperature ranges from $15-45^{\circ} \mathrm{C}$.

\section{Geology}

The geology of the investigated area is complex, and reflects its position at the edge of the Arabian and African tectonic plates.
The project site lies on the eastern side of the Wadi Araba, the southern part of the Dead Sea Transform (DST) Fault System, in an area where other major faults include the Dana and Salawan, which also cross-cut the area in an east-west direction. The most prominent features of the area are the variety of crystalline basement rocks, the main units of which are the 'Aqaba Complex' and the 'Araba Complex'. Both complexes are comprised of Late Proterozoic plutonic granitoids and extrusive (volcanic) acid and basic rocks, and dikes of variable composition from basalt-dolerite to ryholite. These basement rocks are overlain by a long sequence of stratified rocks, which include various formations of sandstones, siltstones, shales and limestone of Lower Paleozoic and Mesozoic age. These early sedimentary strata are overlain by a further sequence varying between sandstones and limestone, the Disi and Kurnub sandstone formations and the Na'ur limestone formation.

The geological map and geological formations of the project area are presented in Figures 2 and 3 respectively. 


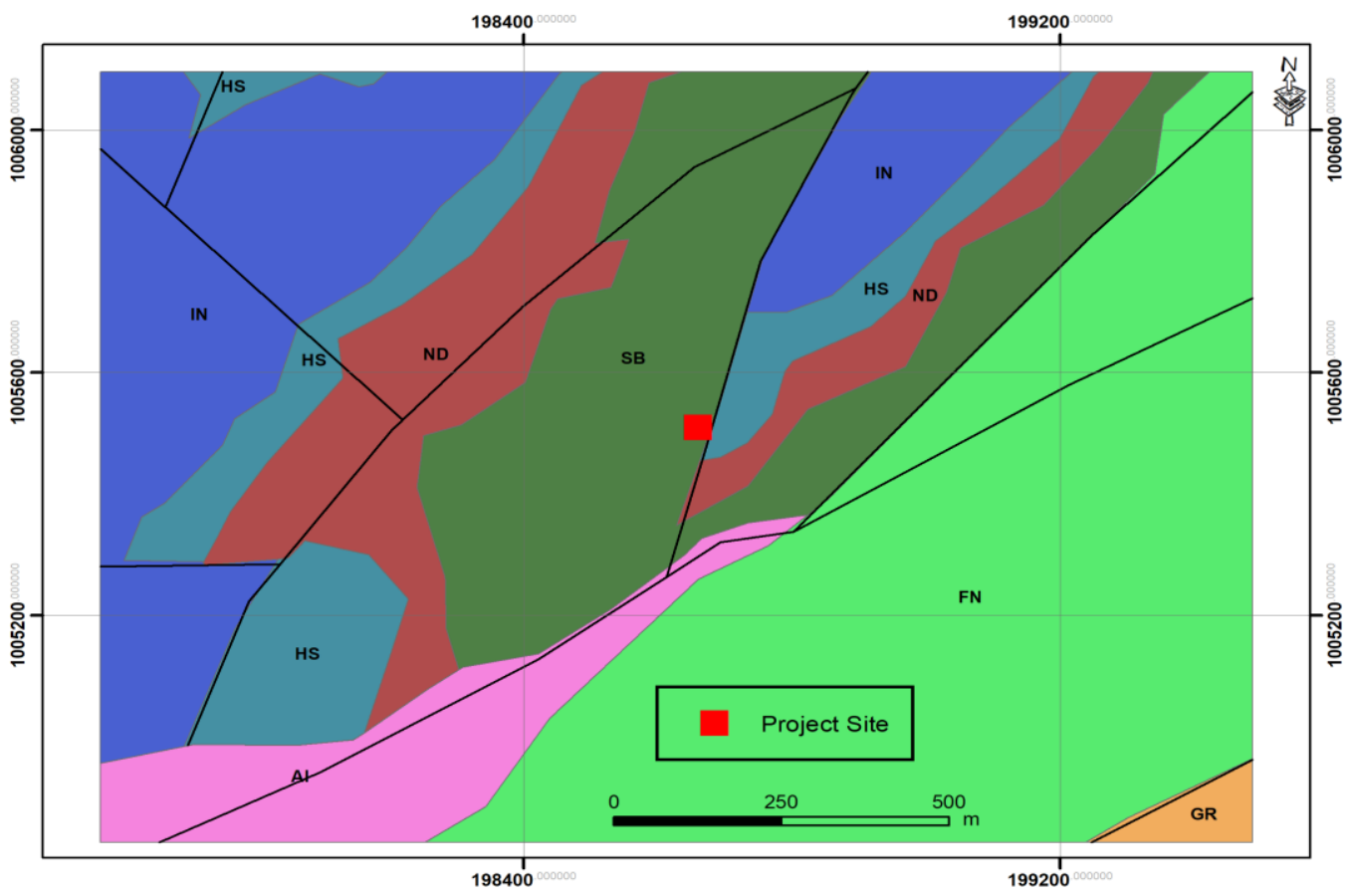

Figure 2: Geological map of the Project Area

$\begin{array}{lll}\text { Symbol } & \text { Formation } & \text { Group } \\ \text { Al } & \text { Alluvium and Wadi Sediments } & - \\ \text { HS } & \text { Burj Dolomite Shale } & \text { Ram Sandstone } \\ \text { IN } & \text { Umm 'Ishrin Sandstone } & \text { Ram Sandstone } \\ \text { ND } & \text { Burj Dolomite Shale } & \text { Ram Sandstone } \\ \text { SB } & \text { SalibArkose } & \text { Ram Sandstone }\end{array}$

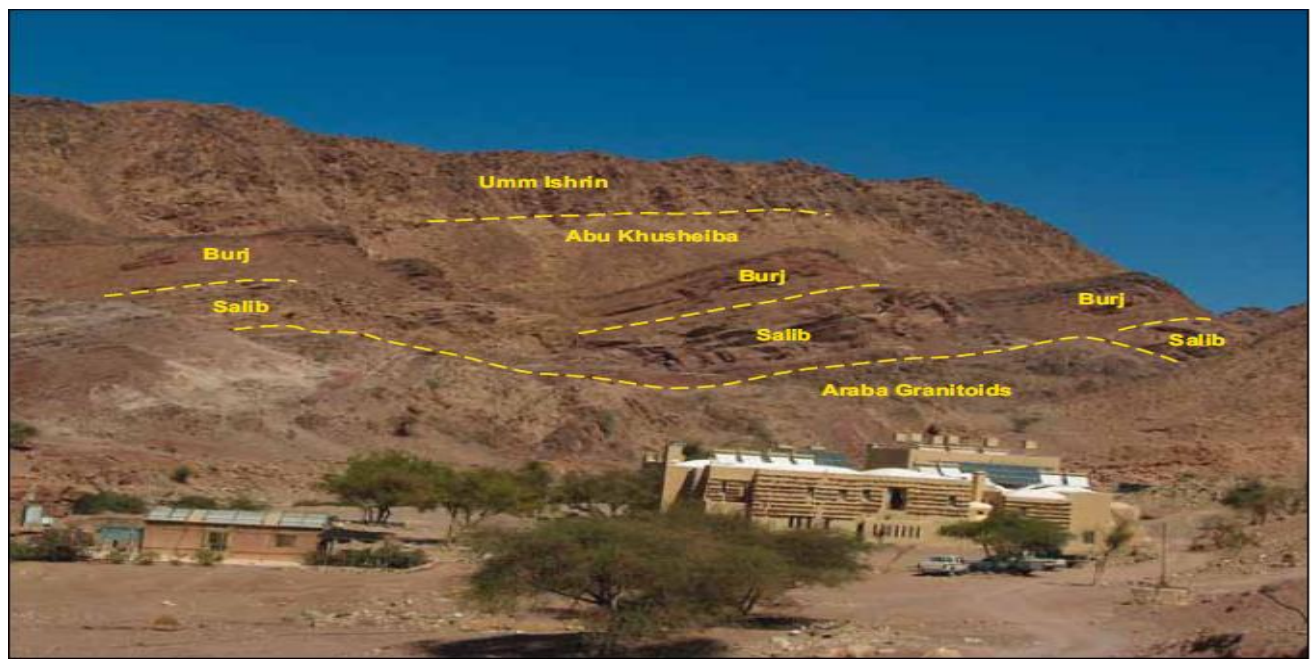

Figure 3: Geological Formations at the Project site

It is anticipated that the floor of the wadis in the project area is underlain great thickness of weathering materials drained to the area since the Pleistocene. These deposits are possibly underlain by weathered granitic rocks similar to those outcropping within the premises of the investigated region. 


\section{Water Resources}

The project area is part of Wadi Araba North basin. The range of depth to water in the basin is from $25 \mathrm{~m}$ to $80 \mathrm{~m}$, while the range of well depth is from $50 \mathrm{~m}$ to $300 \mathrm{~m}$. The aquifer system in the basin consists of:

- The upper aquifer system: alluvial aquifer.

- The intermediate aquifer system:

$\begin{array}{lrr}\text { Amman-Wadi } & \text { Sir(B2/ } & \text { A7),Nau'r } \\ \text { Aquifer (A1/2) } & \text { and }\end{array}$

Hummar Aquifer (A4).

- The deep aquifer system: Rum and Kurnub.

Groundwater is considered as the main water resources in the project area, discharged mainly from precipitation to the entire catchment area. The project site is located within Wadi Feynan catchment area which drains the eastern scarp slope of Wadi Araba, south of the Dead Sea, and is approximately $25 \mathrm{~km}$ long flowing east to west. The Wadi Feynan $(241 \mathrm{~km} 2)$ disgorges to Wadi Araba after passage through the Jebel Hamrat al Fidan, an Aplite-granite mass located at the mouth of the Wadi Fidan; the Wadi Fidan is the name given to the extension of Wadi Feynan between Al Qurayqira and Jebel Hamrat al Fidan.

The Wadi Feynan has two major tributaries, the Wadi Ghuwayr and the Wadi Dana, developed along two NE-SW trending geological faults (Figure 4). The B2/A7 formation is considered to be one of the most important groundwater reservoirs in the investigated area. It is composed of limestone, marly limestone with chert bands, chalk, and dolomite limestone.

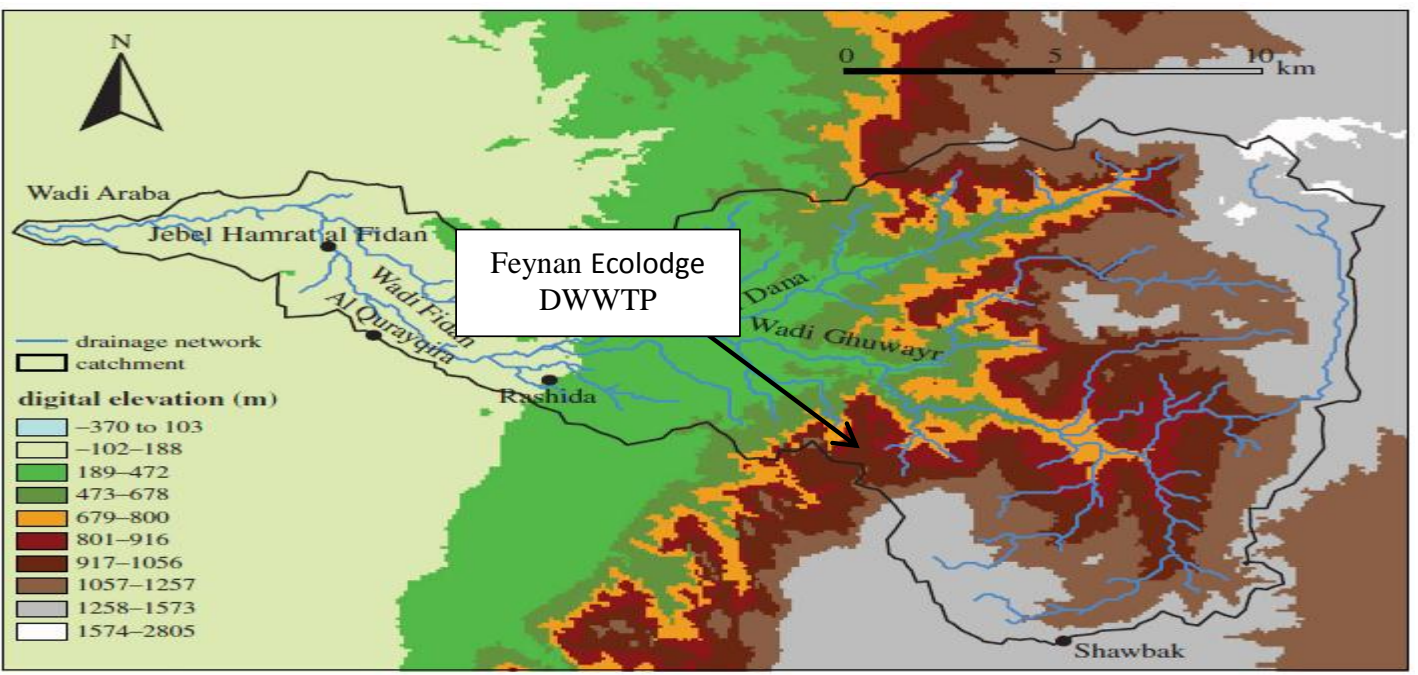

Figure 4: Topographic and Hydrological Map of the Project Area

Spring water within Wadi Araba North basin where the project site is located is one of the major sources for drinking water and irrigation activities. 2 The altitudes of the

${ }^{2}$ Omar A. Al-Khashman, Hani M. Alnawafleh, Ahmad M. Abu Jrai1, Ala'a H. Al-Muhtaseb, springs range from $660-1540 \mathrm{~m}$.Springs are also found in the Wadi Dana and are used to irrigate gardens and to supply a hotel, but rarely any surface water flows in the wadis.

"Monitoring and Assessing of Spring Water Quality in Southwestern Basin of Jordan", Open Journal of Modern Hydrology, 2017, 7, 331-349 


\section{Project Technology}

The project constitutes a sustainable lowmaintenance solution incorporating different modules of a close-to-nature system using indigenous plants as well as local filter materials. A biogas component using the produced gas for cooking and the reuse of the treated WW for irrigation of native trees complement the idea of a WW treatment and reuse approach for Feynan Ecolodge.

The DWWTP will have a treatment capacity of approximately $5-10 \mathrm{~m} 3 / \mathrm{d}$. The technology selected for the DWWTP consists of primary treatment in a biogas settler(black water and kitchen WW) and secondary anaerobic treatment in an ABR (effluent of biogas settler and grey water). Tertiary treatment will take place in an aerobic vertical flow constructed wetland (VFCW) prior to water storage for reuse.

The technology consists of (Figure 5): kitchen WW streams. In addition organic solid waste (e.g. kitchen waste, cardboard boxes) generated on site will be added to the digester.

- Anaerobic Baffled Reactor (ABR) as secondary treatment: The average flow of WW generated on site is $5 \mathrm{m3} / \mathrm{d}$. $100 \%$ will be recirculated through the $A B R$ and $V F C W$ in order to guarantee that the discharge standards for Nitrate (JS 893/2006, Category C) are achieved. During high peak flows (high tourist seasons) the water will not be recirculated.

- Vertical Flow Constructed Wetland (VFCW) as tertiary treatment with an average treatment capacity of $10 \mathrm{~m} 3 / \mathrm{d}$ (after recirculation).

- After treatment, the water will be reused for irrigation purpose and hence pumped to an irrigation collection tank with a proposed storage capacity of $20 \mathrm{~m}^{3}$.

- Black water treatment in a biogas digester

as primary treatment for the black water and

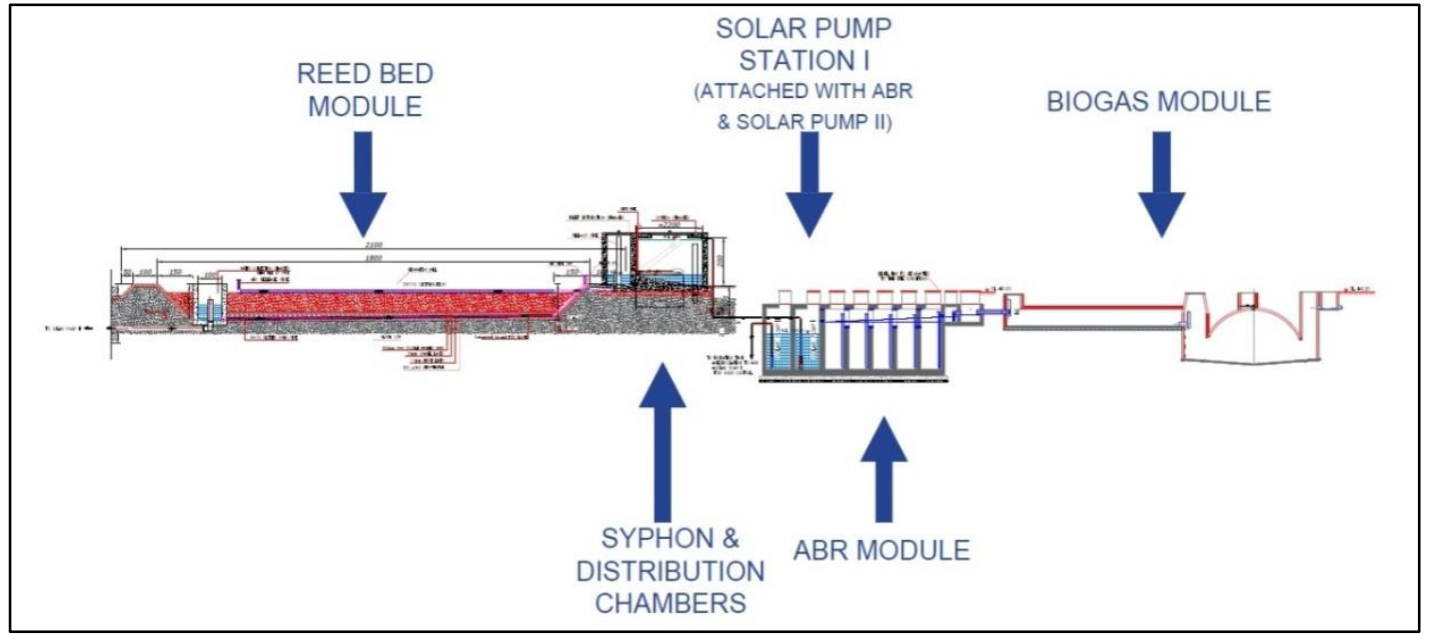

Figure 5: Architectural design of the DWWTP in Feynan Ecolodge - cross section 


\section{The design for the small-scale}

\section{DWWTP and reuse system} contains the following components:

- Connection component: conjunction of the

kitchen WW to the black water sewer and connection of the treatment system to the existing separate black water and grey water sewers.

- Black water treatment in a biogas settler (primary treatment).

- Merging of the grey water (from existing sewer) and pretreated black water (outlet of biogas settler) streams in a manhole.

- Anaerobic Baffled Reactor (ABR) (secondary treatment).

- Distribution system with solar-pump, floating valve and distribution chamber.

- Vertical-Flow Constructed Wetland (VFCW) (tertiary treatment).

- Recirculation of VFCW effluent to ABR for denitrification process.

- Re-use collection tank.

The process is being described in Figure 6.

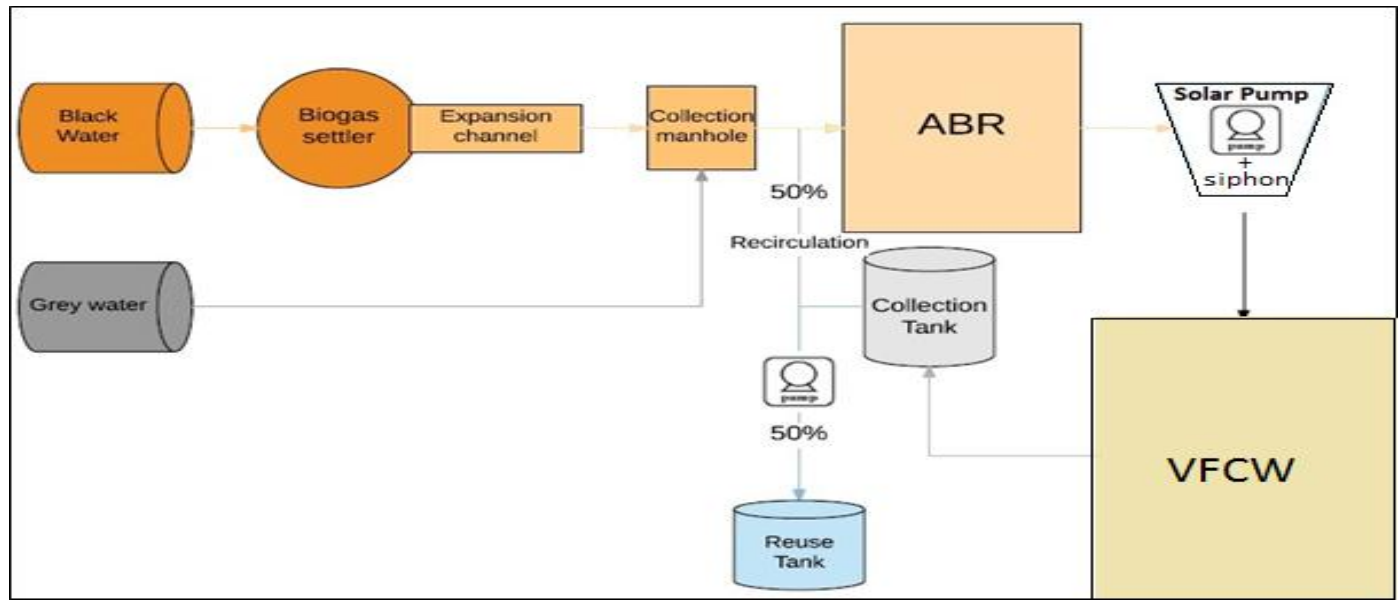

Figure 6: Flow chart wastewater treatment system at Feynan Ecolodge

The implementation of a new WW treatment concept should be integrated into the existing infrastructure as far as possible. Hence, it is proposed to connect the DWWTP to the existing sewerage system of the lodge. As the black water stream and the grey water stream shall be still separated for the primary treatment, two different connection / mixing points are suggested, thus a connection to the black water sewer (toilet, staff house and kitchen WW) as well as a connection to the grey water sewer (showers, hand washing, cleaning).
Impact on Groundwater Resources

There will be always the risk that a contamination incident could result in pollution of the soil and/or groundwater in case of malfunctions. These risks are expected to be insignificant given the quantities of wastewater which are very low (approximately 5-10m3/d), simple and appropriate technology chosen with lowmaintenance.

Groundwater is considered as the main water resources in the project area, 
discharged mainly from precipitation to the entire catchment area and the range of depth to water in the project area is from $25 \mathrm{~m}$ to $80 \mathrm{~m} 3$. But the precipitation is too low in project area (less than $100 \mathrm{~mm} / \mathrm{year}$ ). The altitudes of the springs within Northern Wadi Araba basin where the project site is located range from $660-1540 \mathrm{~mm}$, while the altitude of the project site is around $350 \mathrm{~m}$ above sea level. On the other hand, the DWWTP will be protected by a flood-protection and VFCW area will be also properly lined; therefore any possibility of wastewater flow to the groundwater or nearby springs is highly unlikely.

The project as previously mentioned foresees reuse of the treated effluent for restricted irrigation purposes of fodder, industrial crops and forest trees (JS893/2006, Category C). No discharge of treated wastewater into wadis is expected. In case of overflows, the treated water will be routed into an infiltration pit next to the DWWTP.

Reclaimed water can also contain significant quantities of plant beneficial ions (nutrients) such as nitrogen, phosphorus and potassium. But soil salinity may increase when using treated wastewater in irrigation especially in limited rainfall area such as the project site which can decrease productivity in the long term. Therefore it is necessary to control the salinity when using treated wastewater for irrigation.

\footnotetext{
${ }^{3}$ Omar A. Al-Khashman, Hani M. Alnawafleh, Ahmad M. Abu Jrail, Ala'a H. Al-Muhtaseb, "Monitoring and Assessing of Spring Water Quality in Southwestern Basin of Jordan", Open Journal of Modern Hydrology, 2017, 7, 331-349
}

\section{Ground water Contamination Risk}

To determined the impact of waste which's mention above and if its causes any expected risk to groundwater contamination, DRASTIC Model is applied to evaluate the groundwater vulnerability to pollutant in the project area.

DRASTIC model was developed by EPA as "A Standards System for Evaluating Ground water Pollution Potential of Hydrogeology Settings “, a numerical value for the DRASTIC index is a combination of rating and weights.

There are many measurable

factors for each hydrogeologic

setting related to DRASTIC

\section{methodology. The factors include:}

Depth to Water (D):

There is greater chance for the contamination to reach and pollution the ground water at shallow aquifer more than deep aquifer.

\section{Recharge (R)}

More recharge to the aquifer (in or around the project site), mean more possibility of the pollution to be transported to the ground water. 


\section{Aquifer Media (A)}

The material of the aquifer determines the mobility of the contamination through it .An increase in the time of travel of the pollutant through the aquifer results in more attenuation of the contamination.

\section{Soil Media (S)}

Soils contain clays and silt will be have large water holding capacity, and thus increase the travel time of the contamination through the root zone.

\section{Topography /Slope (T)}

When the topography of the land surface be higher slope, it means, the lower of pollution potential due to higher runoff and erosion rate, these include the pollutant that infiltration into the soil.

\section{Impact of the Vadose Zone}

\section{Material (I)}

The unsaturated zone above the water table is referred to as vadose zone. The texture of the vadose zone determined how long contamination will travel through it.

\section{Hydraulic Conductivity (C)}

The amount of water percolating to the ground water is determined by hydraulic conductivity. The pollutant travel time is decreased within the aquifer if the soils be high permeable.

Numerical relative rating and weight system is the most important feature of DRASTIC model:

\section{Rating:}

Each range for each DRASTIC factor has been evaluated with respect to others to determine the relative significant of each range with respect to pollution potential. The rating of DRASTIC factor will be from 1 to 10.

Range:

Each DRASTIC factor has been divided into either ranges or significant media types which have an impact on pollution potential.

Weight:

The weight represents an attempt to define the relative importance of each factor in its ability to affect pollution transport to and within the aquifer, its range from 1 to 5 .

Tables (2, 3 and 4) represented the ratings and weights for each parameter .Each parameter rating are multiplied by weighting to get a value for the parameter. (These values are then summarized to arrive at a pollution index, called DRASTIC index).

DRASTIC index can be divided to four categories: low, moderate, high and very high .If the site of the project area be high or very high DRASTIC index value it means more vulnerable to contamination and consequently need to be managed more carefully.

\section{DETERMINE THE RATING}

NUMBER FOR EACH FACTOR

\section{Groundwater Depth:}

The depth to groundwater table in the project site range from $50-300 \mathrm{~m}$ at the wells penetrated the top aquifer (B2/A7).

\section{Groundwater Recharge:}

Rainfall at project area is less than $100 \mathrm{~mm} /$ year. Assuming an effective porosity 
Ass. Univ. Bull. Environ. Res. Vol. 21 No. 2 October 2018

of $2 \%$, groundwater recharge would be around $4 \mathrm{~mm} / \mathrm{year}(0.4 \mathrm{~cm})$ or $3 \%$ from the total rainfall.
Generally, the area is rolling to hilly, with some steep wadis., with slope more than $18 \%$.

\section{Topography \%:}

Table 2: DRASTIC Rating and Weights for Each Hydrogeological Setting

\begin{tabular}{|c|c|c|c|c|c|c|c|}
\hline \multicolumn{2}{|c|}{ Depth to Water Table (m) } & \multicolumn{2}{c|}{ Recharge (cm) } & \multicolumn{2}{c|}{ Topography (\%) } & \multicolumn{2}{c|}{ Conductivity (m/d) } \\
\hline Range & Rating & Range & Rating & Range & Rating & Range & Rating \\
\hline $0-1.6$ & 10 & $0-5$ & 1 & $0-2$ & 10 & $0.041-4.1$ & 1 \\
\hline $1.6-4.6$ & 9 & $5-10.2$ & 3 & $2-6$ & 9 & $4.1-12.3$ & 2 \\
\hline $4.6-9.1$ & 7 & $10.2-17.8$ & 6 & $6-12$ & 5 & $12.3-28.7$ & 4 \\
\hline $9.1-15.2$ & 5 & $17.8-25.4$ & 8 & $12-18$ & 3 & $28.7-41$ & 6 \\
\hline $15.2-22.9$ & 3 & $>25.4$ & 9 & $>18$ & 1 & $41-82$ & 8 \\
\hline $22.9-30.5$ & 2 & & & & & $>82$ & 10 \\
\hline \multicolumn{2}{|c|}{30.5} & 1 & \multicolumn{2}{|l|}{ Pollution Weight 4 } & Pollution Weight 3 & Pollution Weight 2 \\
\hline \multicolumn{2}{|l|}{ Pollution Weight 5 }
\end{tabular}

(Bloods values are those applications to project area)

Table 3: The Rating and Weights for Each Hydrogeological Setting

\begin{tabular}{|c|c|c|c|}
\hline \multicolumn{2}{|l|}{ Aquifer Media } & \multicolumn{2}{|l|}{ Vadose Zone Material } \\
\hline & Rating & & Rating \\
\hline Massive Shale & 2 & Confining Layer & 1 \\
\hline Metamorphic / Igneous & 3 & Silt / clay & 3 \\
\hline Weather Metamorphic Igneous & 4 & Shale & 3 \\
\hline Glacial Till & 5 & Limestone & 3 \\
\hline Bedded Sandstone, Lime stone & 6 & Sandstone & 6 \\
\hline Massive Sandstone & 6 & Bedded Limestone, Sandstone & 6 \\
\hline Massive Limestone & 8 & Sand and Gravel With Signification Silt & 6 \\
\hline Sand and Gravel & 8 & Sand and Gravel & 8 \\
\hline Basalt & 9 & Basalt & 9 \\
\hline Karsts Limestone & 10 & Karsts Limestone & 10 \\
\hline Pollutant Weight 3 & & Pollutant Weight 3 & \\
\hline
\end{tabular}


Table 4: The Rating and Weights for Each Hydrogeological Setting

\begin{tabular}{|c|c|}
\hline \multicolumn{2}{|c|}{ Soil Media } \\
\hline & Rating \\
\hline Gravel & 10 \\
\hline Sand & 9 \\
\hline Peat & 8 \\
\hline Shrinking Clay & 7 \\
\hline Sandy loam & 6 \\
\hline Loam & 5 \\
\hline Silty Loam & 4 \\
\hline Clay Loam & 3 \\
\hline Pollutant Weight 5 & \\
\hline
\end{tabular}

\section{Hydraulic Conductivity:}

Due to karst features, joint, sink holes, caves and solution breccias, B2/A7 aquifer has a wide range of hydraulic conductivity values range from $0.0846 \mathrm{~m} / \mathrm{day}$ to $8.64 \mathrm{~m} / \mathrm{day}$.

\section{Aquifer Media and Vadose Zone} Material:

The B1 formation is intercalated between $\mathrm{B} 2$ and $\mathrm{A7}$, this formation (B1) composed of alternating marl, marly limestone, chert and sandstone. B2/A7 formation is an excellent aquifer with permeability varying due to joints, fractures and karstification of limestone.

\section{DRASTIC Index Calculation}

DRASTIC Index for the project area is calculated and shown in table (5) :

Table 5: DRASTIC Index Calculation

\begin{tabular}{|l|c|c|c|c|}
\hline \multicolumn{1}{|c|}{ DRASTIC Factor } & Range & Rating & Weight & Result \\
\hline Depth to W.T. ( $\mathrm{m})$ & $>30.5$ & 1 & 5 & 5 \\
\hline Recharge (cm) & $0-5(0.6 \mathrm{~cm})$ & 1 & 4 & 4 \\
\hline Topographic/Slope (\%) & $>18$ & 1 & 3 & 3 \\
\hline Conductivity (m/day) & $4.1-12.3(0.0846-8.64)$ & 2 & 2 & 4 \\
\hline Aquifer Media & Karst Limestone & 10 & 3 & 30 \\
\hline Vadose Zone Media & Bedded Sandstone , limestone & 6 & 3 & 18 \\
\hline Soil Media & Sand & 9 & 5 & 45 \\
\hline DRASTIC index & & & & 109 \\
\hline
\end{tabular}

The DRASTIC Index usually range from a minimum 23 and maximum 230 (if the value be less than 120 its mean the low vulnerability range of groundwater contamination). The higher of DRASTIC Index means greater the ground water pollution potential.
The DRASTIC Index value is 109 , this value closed to the number (120) which means, there will be some potential impact on groundwater resources in the area from this project, if there is no serious mitigation measures applied. 


\section{REFERENCES}

AlineBussmann, Leonard Dlubatz, AbdallaKhair, FirasMatar, Ismael Nouns, Elke Zimmermann and Mandy Zuchold, February 2014, Feynan Ecolodge Integrated Potential Water and Wastewater Treatment Solutions - Blind Design, Developed by IWRM Alumni Association

Bender, F., 1968, Geologie von Jordanien, Bietrage zur regionalen geologie der erde, Geological Survey of Germany, Berlin

Bender, F., 1974, Geology of Jordan, Berlin: Gebrüder Borntraeger, 196pp

BORDA west and central Asia and GIZ, September 2017, Technical Design Report for a Decentralized Wastewater Treatment System at Feynan Ecolodge, Dana

Eng. Nayef Seder (JVA) and Eng. Sameer Abdel-Jabbar (GIZ), 2011, Safe Use of Treated Wastewater in Agriculture - Jordan Case Study, prepared for Arab Countries Water Utilities Association (ACWUA)

John H. Powell, Abdulkader M. Abed and YvesMichel Le Nindre, Cambrian stratigraphy of Jordan,GeoArabia, 2014, v. 19, no. 3, p. 81134.

Malek M. Jamaliah\& Robert B. Powell (2017): Ecotourism resilience to climate change in Dana Biosphere Reserve, Jordan, Journal of Sustainable Tourism,

DOI: 10.1080/09669582.2017.1360893

Ministry of Water and Irrigation, Decentralized Wastewater Management Policy, 2016

Ministry of Water and Irrigation, Water Substitution and Reuse Policy, 2016

Omar A. Al-Khashman, Hani M. Alnawafleh, Ahmad M. Abu Jrail, Ala'a H. AlMuhtaseb, "Monitoring and Assessing of Spring Water Quality in Southwestern Basin of Jordan", Open Journal of Modern Hydrology, 2017, 7, 331-349

Sasse, L., 1998, Decentralized Wastewater Treatment in Developing Countries, BORDA SuhailSharadqah, 2014, Climate Change Trends in Tafila Governorate (Central West Jordan) in the Period 1938- 2006, Journal of Natural Sciences Research, Vol.4, No.10

Stuckey, D. C.; H. H. P. Fang (Editor), 2010, Anaerobic Baffled Reactor (ABR) for Wastewater Treatment, In: H. H. P. Fang (Editor) (2010): Environmental Anaerobic Technology, London

Tarawneh,B. 1988, The Geology of At Tafila, Geology Directorate, Geological Mapping Division, Natural Resources Authority, Bull,12

The Study on Water Resources Management in The Hashemite Kingdom of Jordan, Final Report/Supporting Report Part-A "Master Plan", Supporting Report for "Chapter 2 Water Resources Potential and Development Plan"

Tilley, E.; Ulrich, L.; Luethi, C.; Reymond, P.; Zurbruegg, C., 2014, Compendium of Sanitation Systems and Technologies, 2nd Revised Edition, Duebendorf, Switzerland: Swiss Federal Institute of Aquatic Science and Technology (Eawag)

UNDP and GEF, Jordan's Third National Communication on Climate Change, submitted to UNFCCC, 2014

Wade, A.J., Black, E., Brayshaw, D.J., ElBastawesy, M., Holmes, P.A.C., Butterfield, D., Nuimat, S., Jamjoum, K. 2010, “A modelbasedassessment of theeffects of projectedclimatechangeonthewaterresources of Jordan", Journal of Mathematical, Physical and Engineering Sciences, vol. 368, pp. 5151-5172 


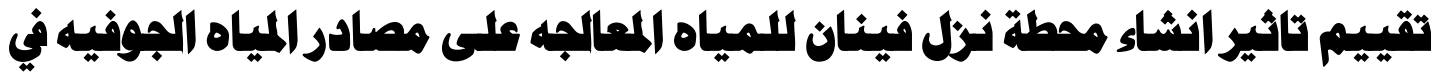 منطقة ضانا - همانظة الطفيله - دراسة ماله في جنوب الآردن د. دمشمود العلاونه}

وزارة المياه والري/ سلطة المياه

\section{الالفص العربي :}

تتمثل الأهداف الرئيسية لهذا المشروع في تعزيز تكنولوجيات معالجة مياه الصرف الصحي اللامركزية المرنة والمستدامة بالإضافة إلى إعادة استخلام المياه العادمة المعالجة ، في حين تهذف هذه الاراسة إلى تقييم آثار هذا المشروع على مصادر المياه الجوفيه في المنطقة من خلال تطبيق نموذج دراستك في هذه الورقة لتقييم الثاثيرات على المياه الجوفيه تم حساب العديد من العو امل المختلفة وبالتالي حساب مؤشر دراستك .

تم دعم هذا المشروع من خلال الحكومه الاتحاديه للجمهورية الالمانيه ممثلة بوزارة الاقتصاد والتعاون الدولي من اجل التكيف مع التغيير المناخي الحاصل في الاردن والتي تقوم بتشجيع الثركاء والجمعيات في ادارة و انثاء محطات المعالجه اللامركزيه كمقياس للتغير المناخي ـ ايضا هذا المشروع تم بالتعاون وزارة المياه والري / سلطة المياه ـ تم انثاء هذه المشروع ضمن محمية ضانا التي تعتبر محميه طبيعيه وكنلك بالتعاون مع الجمعيعه العلميه الملكيه لحماية الطبيعه و الثركاء المحلين ايضا . كاجراء للتكيف ، يشجع المشروع على الاستخذام الفعال لموارد المياه من خلال نهج مزدوج: حماية مصادر المياه من خلال تقليل نسب باستخدام المياه المعالجه وينفس الوقت فان عملية استخدام المياه المعالجة في الزراعات المقيده يخفف من الطلب على المياه العذبه المستخدمه التي في العاده ما تستخدم في الزراعه . الكالمات الرثُمسيه : نموذج دراستك، مؤشر دراستك،مصادر المباه الجوفيه، التغيير المناخي 